\title{
THE VOID FOR VAGUENESS RULE IN CALIFORNIA
}

The recent cases of People v. King, ${ }^{1}$ People v. Saad, ${ }^{2}$ Wooton v. Bush, ${ }^{8}$ and Orloff v. Turf $\mathrm{Club}^{4}$ call attention to a notable development in California law. There has been an increase in the number of cases involving the judge-created doctrine which permits courts to hold that statutes are void because they are too vague. The doctrine is still developing; ${ }^{5}$ predictability is difficult; there are frequent dissents and reversals of lower courts; many holdings seem to be contradictory. ${ }^{\circ}$

In People v. Saad, a statute using the words "touting or practices inimical to the public interest" was held to be so vague as to violate due process. ${ }^{7}$ The ordinance involved in People v. King, which prohibited barmaids from "mingling" with patrons, was upheld - as were the words "person of lewd or immoral character," questioned in Orloff v. Turf Club. In Wooton v. Bush the Oil Well Spacing Act which contained the words "field" with no definition was held not void for vagueness. The purpose of this comment is to inquire into this rule to see if there is some way to resolve the cases and whether any light can be shed on how the rule will be applied in the future.

\section{Statement of the Concept}

Void for vagueness breaks into two main elements: (1) guide to conduct, and (2) guide to adjudication. In the Saad case the defendant was warned by the statute that if he was a person guilty of "practices inimical to the public interest" he must leave a race track when asked. ${ }^{8}$ The court held that this was not a sufficient guide to conduct. Citmg the United States Supreme Court," the court said: "No one may be required at his peril of life, liberty or property to speculate as to the meaning of penal statutes." 10

1115 A.C.A. 345, 252 P.2d 78 (1952). San Diego Municipal Code, Sec. 33.1541.1.

2105 Cal. App. 2d 851, 234 P.2d 785 (1951). CaL. PEN. Code $\$ 337.5$.

341 A.C. 469, ....... P.2d ....... (1953). Cal. Pub. Res. Code $\$ 3600-3608$. This reversed the district court which had held the statute void. 114 A.C.A. 895,251 P.2d 376 (1952).

436 Cal. 2d 734, 227 P.2d 449 (1951). CaI. Crv. Code \$ 51-54.

5 This rule has grown from the common law rule of strict construction in favor of the defendant. See Ex Parte Kohler, 75 Cal. 38, 15 Pac. 436 (1887). This case should be contrasted with People v. Bradford, 95 Cal. App. 2d 372, 378, 213 P.2d 37, 40 (1949) where the court said: "The rule of common law that penal statutes be strictly construed has no application to this code. All its provisions are to be construed according to the fair import of their terms with a view to effect its objects and promote justice."

"For general discussion of the void for vágueness problem, see 62 HARv. L. REv. 77 (1948), 29 Carri. L. Rev. 548 (1941), 96 PENN. L. REv. 889 (1947).

7 The first case to put the void for vagueness rule in terms of due process in California was Ex Parte Lockett, 179 Cal. 581, 178 Pac. 134 (1919).

8 CAL. PEN. Code $\$ 337.5$ provides: "Any person who has been convicted of touting ... or any person who has been ejected from any race track of this state or any other state for touting, or practices inimical to the pubhic interest, shall be excluded from all race tracks in this state. Any such person who refuses to leave such track when ordered ... is guilty of a misdemeanor."

9 Lanzetta v. New Jersey, 306 U.S. 451 (1939).

10 The court also cited from Connally v. General Construction Co., 269 U.S. 385, 391 (1926): "That the terms of a penal statute creating a new offense must be sufficiently explicit to inform those who are subject to it what conduct on their part will render them hable to its penalties, is a well-recognized requirement, consonant alike with ordinary notions of fair play 
In Wooten v. Bush the District Court of Appeals noted when discussing the word "field" in the Oil Well Spacing Act, that a person had no warning of what he could or could not do and still not violate the statute.

Guide to adjudication, the second element, is usually expressed as a requirement that there be a fixed standard of guilt. The United States Supreme Court used this standard in Cline v. Frink Dairy ${ }^{11}$ which was subsequently cited in the Califorma case of Ward v. Auctioneers. ${ }^{12}$ In holding the statute void for vagueness the Ward case said "reasonable profit" left "the whole statute without a fixed standard of guilt in an adjudication affecting the liberty of one accused." The first element, warning, involves an inquiry into the question of whether a particular statute informs the defendant of what he can and can not do. The second element, guide to adjudication, involves the question whether the statute gives a judge and jury a standard which they can uniformly apply to persons accused.

\section{GUIDE TO ADJUDICATION}

Even if everyone is supposed to know the law, they are not presumed to know it better than the judges. It would seem therefore that guide to adjudication forms the backbone of the void for vagueness rule. Not a single case has been found where the judges have said that they understand the statute, but that it would not be understandable to a prospective defendant. It seems that if it is understandable to the court, that is enough. All the cases which have held there was "no warming" to a defendant, could just as easily have been couched in terms of "no standard of adjudication for a court."

Naturally, the court will normally discuss a case to decide the issues raised in argument. If the defendant uses the defense that he was not "warned," the court is likely to put the holding in terms of warning. This may obscure the fact that the ultimate question in close cases is the guide to the judges. In Phillips v. Municipal Court" 13 "every person who annoys or molests a school child or loiters about any school" was held to be adequate warning. There was no need to put the decision on the more fundainental question. ${ }^{14}$ In the Lockett case $\mathrm{e}^{15}$ the statute read: "acts technically

and the settled rules of law. And a statute which either forbids or requires the doing of an act in terms so vague that men of common intelligence must necessarily guess at its meaning and differ as to its application, violates the first essential of due process of law."

11274 U.S. 445 (1927).

1967 Cal. App. 2d 183, 153 P.2d 765 (1944), cert. denied, 325 U.S. 874 (1944). This involved CAL. Bus. \& Prof. Code § 16723, Cal. Stats, 1951, p. 1834. "No agreement, combimation or association is unlawful or within the provisions of this chapter, the object and purpose of which are to conduct operations at a reasonable profit or to market at a reasonable profit those products which cannot otherwise be so marketed."

1324 Cal. App. 2d 453, 75 P.2d 548 (1938).

14 In People v. Pallares, 112 Cal. App. Supp. 2d 895, 246 P.2d 173 (1952), the statute said: "Every person who annoys or molests any child under the age of 18 is a vagrant." The defendant claimed that since "annoy" and "molest" are vague and subjective and because "18" did not refer to days, weeks, or months, the statute was void for vagueness. Here again the court held there was sufficient warning provided by this statute. Of course, there was no need to refer to the standard of guilt, the statute does say what it means. There may be a concept which might be called "standing to complain." Should a person who speeds at 100 miles per hour in a city, be heard to complain that the speed law is vague? This concept has been brough". out by the U.S. Supreme Court in Screws v. U.S., 325 U.S. 91 (1945).

15 Supra note 7. 
known as fellatio and cunnilingus are declared to be felonies." The court spoke of the requirement that "people of ordinary intelligence" should be fairly warned by a statute. ${ }^{16}$ Yet, closer examination shows clearly that even the court had no definite idea of what the words meant. There was no standard of guilt for the court to apply. Whether "men of ordinary intelligence" would be warned by the statute is the criterion used in many cases, ${ }^{17}$ yet the courts demand that the "man of ordinary intelligence" know common law terms, precedents, and well settled doctrines. There is little doubt that if the court in the Lockett case had felt that "cunnilingus" and "fellatio" had a standard definition to which it could resort, there would have been no void for vagueness holding. ${ }^{18}$

Guide to adjudication is a more flexible standard which meets the demands of modern statutes. In Ex Parte Daniels ${ }^{\mathbf{1 9}}$ the court stated that in the future there would be a more liberal construction put on statutes involving penalties. ${ }^{20}$ This involved "safe and reasonable speed" in one of California's early traffic statutes. Obviously the legislature could not establish a speed limit for every road and intersection in the state, so something less than a specific mile per hour limit had to be a satisfactory standard. The judge or jury were deemed to have enough of a standard by reference to the reasonably prudent man of tort fame, i.e., "what would a reasonably prudent man think was a reasonable speed." This type of inquiry has been the rationale for upholding many statutes which by their very nature and subject matter could not be more clear. ${ }^{21}$ "Willful and wanton" ${ }^{22}$ is clear enough. "Drunk to the annoyance of others" 23 affords a standard. "Necessary to preserve life" ${ }^{24}$ is adequate. "Diligence to find the owner" ${ }^{25}$ has been upheld. "Unjustifiable physical pain or mental suffering" ${ }^{26}$ withstood

16 Ex Parte Lockett, supra note 7 at 588, 178 Pac. at 137.

17 See Wooten v. Bush, supra note 3, People v. Pace, infra note 45, United States v. Reese, 92 U.S. 214, 220 (1875) and Connally v. General Construction Co., supre note 10.

18 The court had searched through everything from Havelock Ellis to Black's Law Dictionary trying to find a uniform interpretation of the words. If one had been found, the defendant would have been held to have received "warning" from this statute.

19183 Cal. 636, 192 Pac. 442 (1920).

20 "There has been a tendency towards a more liberal construction of such statutes in the more recent decisions." The court cited Standard Oil Co. v. U.S., 221 U.S. 1 (1910) where the court in interpreting the anti-trust law adopted the "rule of reason." Even this late, the dissent in the California case was arguing for strict construction of penal statutes, in the face of Cat. Pen. Code $\$ 4$.

21 See People v. Yates, 114 Cal. App. Supp. 782, 789, 298 Pac. 961, 964 (1931) where the court in discussing the clarity of "necessity" said: "In the nature of things no specific and precise rule can be inade on the subject.... The necessity is capable of ascertainment by proof to be submitted to the jury."

22 People v. Sinith, 36 Cal. App. Supp. 2d 748, 92 P.2d 1039 (1939). People v. Crossan, 87 Cal. App. 5, 261 Pac. 531 (1927) discusses Cax. Pen. Code $\S 192$ ("due caution and circumspection").

23 People v. Beifus, 22 Cal. App. Supp. 2d 755, 67 P.2d 411 (1937).

24 People v. Gallardo, 243 P.2d 532 (1952) rev'd on other grounds, 41 A.C. 56,257 P.2d 29 (1953).

25 Pacific Coast Dairy v. Police Court, 214 Cal. 668, 8 P.2d 140 (1932).

20 People v. Curtis, 116 Cal. App. 771, 300 Pac. 801 (1931). 
the void for vagueness attack. "Adequate protection to effectively minimize spray" 27 is deemed to be an adequate standard.

The King case ${ }^{28}$ involved an ordinance prohibiting female employees of bars from "drinking, dancing or mingling" with patrons. The defendant was charged with "mingling." The appellate court mentioned the warning element but admitted that it was not likely the "defendant would consider the words in context before acting." 20 The real point made by the court is that it would be impossible for the legislature to specify each act which would be a violation, and that therefore a standard would be derived from looking at the intent of the legislature, its purpose and considering the words together. It would seem that if "warning" were a valid requirement, it would be suffering great diminution by many of these cases.

Language has been used which might lead to the conclusion that a court is free to manufacture a standard. This would certainly negate any inquiry into the warming furnished, but seems to go too far in the other direction. The leading case of Pacific Coast Dairy v. Police Court ${ }^{30}$ quoted from an Indiana case $e^{31}$ to the effect that: "a court cannot nullify the enactment of the legislature because the language used is indefinite in some particular, uuless the purpose and intent of the legislature cannot be ascertained." The Saad case ${ }^{32}$ would seem to indicate that the California courts are not ready to go this far. The legislative purpose was clearly to keep touts and gamblers away from the race tracks. Yet, even with the legislature's purpose clearly known, there was not a workable standard furnished by "practices inimical to the public interest." A court can reasonably construe the words of a statute in the light of legislative intent and purpose, ${ }^{32 a}$ and by using construction nraxims, but it cannot go so far as to manufacture a standard..$^{33}$

The extreme to which construction can go is shown by the Orloff case. ${ }^{34}$ The statute prohibited the proprietor of a public place from excluding

\footnotetext{
26 People v. Kiser, 112 Cal. App. 2d 903, 245 P.2d 1125 (19,52).

28 Supra note 1.

20252 P.2d at 79.

30 Supra note 25 .

31 Hunt v. State, 195 Ind. 585, 146 N.E. 329 (1925).

32 Supra note 2.

32a Legislative intent and objective are very important. Sec Wooton v. Bush, supra note 3. 33 "A legislative act which is so vague, indefinite, and uncertain that the courts are unable, by accepted rules of construction to determine, with any reasonable degree of certainty, what the Legislature intended or which is so incomplete or conflicting and inconsistent in its provision that it cannot be executed, will be declared to be inoperative and void." Balzer v. Caler, 74 P.2d 839, 845 (1937). Wholesale Tobacco Dealers Bureau v. National Candy and Tohacco Co., 74 P.2d 848 (1937) as a companion case. These cases involved the terms "cost or replacement cost" in the Unfair Practices Act, § 3, Cal. Stats. 1937, ch. 860, p. 2395 which says: " .. sales at less than cost; Unlawful . . . to sell or advertise . . . any article . . . or service . . . at less than the cost thereof to such vendor or give, offer to give or advertise . . . any article ... for the purpose of injuring conpetitors and destroying competition ...." On appeal, the California Supreme Court held the issue of vagueness could not be settlcd in these cases becausc the defendant had stipulated that he had sold below cost; therefore, the question will have to bc settled in another case. Wholesale Tobacco Dealers, 11 Cal.2d 634, 82 P.2d 3 (1938); Balzer v. Caler, 11 Cal. 2d 663, 82 P.2d 19 (1938).

34 Supra note 4. See also Paraco v. Dept. of Agriculture, 118 A.C.A. 403, 257 P.2d 981 (1953).
} 
people without good cause, unless they are of "immoral character." In an equity suit the court construed the phrases to mean "a person who does something immoral on the premises." It seems questionable whether the court would have gone this far in a case involving a penalty rather than an equity suit.

\section{THE WARNING ELEMENT}

\section{Statutes involving very serious conduct}

From the earliest statements of the void for vagueness rule ${ }^{35}$ the courts have used language wlich puts stress on the warming element. The foundation of the idea is the legal presumption that everyone knows the law, and that therefore the law must be clear. The cases indicate that the purpose of the rule is to insure that a person is not led into the pitfall of believing that he is staying inside the law and then finding that he has violated it. Crimes such as murder, rape, robbery, and arson are perpetrated by people who ordinarily do not sit down and read statutes and speculate as to how they will act. Courts have expressed a "natural law" theory whicl amounts to saying that everyone knows certain acts are bad and that they liave no standing to claim the statute is vague. ${ }^{36}$ Whether there is a fundamental natural law which holds certain things universally "bad" or not, the results of the cases would seem to indicate that the question of warning means little in this area.

The ordinary man does not know the meaning of common law terms, yet statutes embodying these are uniformly uplield. ${ }^{37}$ Statutes such as those covering conspiracy, manslaughter and the various degrees of murder are not void for vagueness even though their intricacies and meanings are difficult even for a trained attorney. Statutes which are less than complete can incorporate the words of other statutes. ${ }^{38}$ Even the terms of Penal Code Section 647, which refers to a "dissolute person," have so far withstood attack. ${ }^{38}$ If warning here means anything, it is merely a test as to whether a defendant could consult an attorney and the attorney would be able to provide a guide to conduct.

35 See Ex Parte Lockett, supra note 7; Ex Parte Kohler, supra note 5; Hewitt v. Board of Medical Examiners, 148 Cal. 590, 84 Pac. 39 (1906).

36 Screws v. United States, supra note 14.

37 Cases cited note 22 supra; Connally v. General Construction Co., supra note 10. In Lorenson v. Superior Court, 35 Cal.2d 49, 216 P.2d 859 (1950) the court said the meaning of "to prevent or obstruct justice" could be easily ascertained by reference to either the common law or other sections of the code.

38 The court in the Palleres case, supra note 14, referred to other code sections which also omitted the words "years" after giving an age in numbers. The court in People v. Commons, 64 Cal. App. Supp. 2d 925, 148 P.2d 724 (1944) incorporated by reference all the meanings of "dangerous weapon" which can be found in California codes. See also People v. Mistriel, 110 Cal.App. 2d 110, 241 P.2d 1050 (1952) and Vaughn v. Board of Police Commissioners, 59 Cal. App. 2d 771, 140 P.2d 130 (1943).

39 See Edelman v. California, 344 U.S. 357 (1953). The U.S. Supreme Court held the record indicated that this defense was not raised on trial but was presented for the first time as the fifth of petitioner's grounds of appeal. The dissent (Black, with Douglas joining), disagreed and proceeded to get to the issue of vagueness. They held the statute too vague to meet the safeguarding standards of due process. 


\section{Marginally disreputable occupations}

Perhaps in certain cases there is a justifiable basis for demanding that the statutes touching such activities as burlesque shows, gambling activities, hostesses in bars, etc., be clear so as to provide a guide to conduct. ${ }^{40}$ The condúct, though inorally reprehensible to some, is still legal. There is no room for a "natural law" theory here. At least this type of person would be more likely to consult the law than would the murderer or rapist. His attorney should be able to advise him, for often he is in the precarious position of straddling the fence of legality. There is little law on this point, and the cases that have come up have not been ones where a person in reliance on the statute was entrapped by its vague meaning.

Conduct which, but for the statunte, is morally "good"

Here, the main consideration is that the defendant could be acting in good faith, trying to obey the law, and still run afoul of it because it was not clear. The important thing is that very often the statutes are in fact consulted, attorneys are consulted, and conduct is planned with the statutes in mind. Ex Parte Schmolk $e^{41}$ furmishes a good example. The Transportation Tax Act" attempted to exempt vehicles operating within "... incorporated cities or towns or the usual transfer delivery zone adjacent thereto ...." The court pointed out that it would be impossible for inany operators to determine when they were required to pay the tax. The statute was held void for vagueness. In Ex Parte Peppers ${ }^{43}$ the statute gave authority to the Secretary of Agriculture to administer an act which was to improve the citrus industry in California. The section in question read: "Oranges shall be considered unfit for shipment when frosted to the extent of endangering the reputation of the citrus industry, if shipped." 44 Certainly by these words alone, a shipper or his attorney would not be able to glean much information. There is a good chance of guessing wrong in good faith, and this is the very risk the warning element of the void for vagueness rule is supposed to avoid. ${ }^{45}$ If the courts are ready to say that statutes should be clear as to warning in areas where it is common knowledge that there is no consultation of them, then, a fortiori, in the business world the statutes should be free of ambiguity.

40 There have been few cases on this point. See People v. Bradford, supra note 5, which involved "pool selling" and "bookmaking." The court held that a bookie would know what these terms meant.

11199 Cal. 42, 248 Pac. 244 (1926).

42 Cal. Stats. 1925, p. 833, \$9.

43189 Cal. 682, 209 Pac. 896 (1922).

14 The regulations promulgated by the administrator were not considered by the court. See discussion of administrative law, infra at note 60 .

45 People v. Pace, 73 Cal. App. 548, 238 Pac. 1089 (1925) held void section 2, subdivision 9 (a) of the Corporate Securities Act, Cal. Stats. 1923, p. 89. This section provided: "Any owner of any security who is not the issuer or underwriter thereof, who sells or exchanges the same for his own account [is excepted from obtaining a broker's license] provided, that such sale or exchange is not made in the course of repeated and successive transactions of like or similar character by him." The court said one contemplating the sale of his securities would be at a loss to know whether he would be liable if he should make one sale every 12 months, 36 months, or every 10 years. One of average intelligence should be able to understand, the court said, but lere actually, his trained attorney would not be able to advise him. 
Another important point to note when discussing the warning element is that often the penalty is only for those who "knowingly," "maliciously," or "in bad faith" violate the law. This might in certain cases preclude any consideration of whether the defendant was trapped by vagueness. ${ }^{46} \mathrm{Be}-$ cause of the slight risk of a person being convicted when he is not "knowingly" or "wilfully" violating the law, this type of statute may receive more lenient treatment as to the warning it furnishes. A good faith mistake of fact where intent is a necessary element in the statute will not lead to a conviction. ${ }^{47}$ This should be contrasted with a mistake of law which under the general California rule will not relieve the defendant of liability ${ }^{48} \mathrm{Bad}$ advice as to the scope of the Securities Act would not be a defense, and the statute would need be clear, whereas if the statute required "intent to defraud," its scope of application could presumably be $\stackrel{m}{m}$ terms less precise and still not be void for vagueness. ${ }^{49}$

Ward v. Auctioneers ${ }^{50}$ introduces a consideration which may be important. The statute under attack read: "no agreement, combination ... is unlawful or within the provisions of this chapter, the object and purpose of which [is] to conduct operations at a reasonable profit or to market at a reasonable profit." The California District Court of Appeals held that the statute was void as furnishing an "impractical" standard. ${ }^{51}$ There was no discussion of the warning element, yet this is the area where fair warning is most justifiable. This calls attention to the fact that even though the courts have discussed all types of cases in terms of warming, the guide to adjudication inquiry is ever present. In the above cases while the courts held that there was no "warning," they also could easily have held there was no adequate standard of guilt. It would therefore seem that a challenge to a statute as void for vagueness will be on safer ground if the "guide to adjudication" point is pursued.

\section{VOID FOR VAGUENESS AND ADMINISTRATIVE LAW}

A distinction must be made between what is called a "self-executing" statute and one which establishes a purpose and policy and grants to an administrator the power to effectuate the policy by rules and regulations. In the former, duties and liabilities are immediately created and the question of whether the statute is void for vagueness is pertinent. In the latter, the statute which delegates to an administrator the power to effectuate a program creates no liability or duty until the administrator puts the pro-

46 See People v. Payless Drug, 25 Cal.2d 108, 153 P.2d 9 (1944). Here, "same locality or trade area" was clear enough while the words "usual transfer delivery zone" was held to be too vague in the Schmolke case, supra note 41 . Differences in the cases are that in Payless Drug, there was provision for injunction and the statute required specific intent. See $25 \mathrm{Cal} .2 \mathrm{~d}$ at 128 , 153 P.2d at 20.

47 People v. Melendrez, 129 Cal. 549, 62 Pac. 109 (1900).

48 People v. McCalla, 63 Cal. App. 783, 220 Pac. 436 (1923).

49 MIller, Craminal Law 157 (1934). A possible exception to the rule on bad advice would be where the advice was "official."

50 Sippra note 12.

51 The statute was identical to the one involved in the Kline case, supra note 17. 
gram into operation. The standard of definiteness in these two types of statutes should be vastly different. The nonself-executing statute which einpowers an administrator to make rules should be able to establish vague standards of conduct and still not be subject to a vagueness attack. ${ }^{62}$ The administrator through his regulations will give meaning to the terms in the statute and people will actually guide their conduct pursuant to the regulations, not the statute. Standards of guilt will be established by the regulations and rules that are promulgated. ${ }^{53}$

In California, however, the establishment of a general policy by the statute and the delegation to an administrator of the power to effectuate this policy has not uniformly saved the statute from being void for vagueness. Also, the unrelated doctrine of separation of powers, that is, the rule against delegation of legislative power to an administrator, has been used as an additional ground for invalidating the statute. The Peppers case involved a statute which contained the vague phrase: "Oranges shall be considered unfit ... if frosted to the extent of endangering the reputation ... of the industry." There was a general statement in the statute as to its purpose and intent. Section 15 empowered the director to "define, promulgate and enforce such rules and regulations as may be necessary." It was argued that granting the power to the administrator to define terms through regulations would make up for any vagueness in the statute. The court rejected this argument. Besides holding the statute void for vagueness, it was also held to be an unconstitutional delegation of legislative power to an administrator. There was language which indicated that if the statute was void for vagueness, it was also an unlawful delegation of power. "If the language is too vague to form the basis of a criminal action, it follows that the act has not defined what shall constitute 'frosted oranges'; not having done so, it is clear that any attempt on the part of an administrative board or officer would be an act of legislation." In the Wooton case the word $^{60}$ the

52 The two Federal cases, United States v. Cohen Grocery, 255 U.S. 81 (1920) and Yakus v. United States, 321 U.S. 414 (1944) illustrate the difference. The World War I price control act was self-executing and declared that it was a crine to charge "an unjust or unreasonable rate or charge in handling or dealing in or with any necessaries." The Suprenie Court said these words did not fix an "ascertainable standard of guilt," and were not adequate to inform persons accused of violations thereof of the nature and cause of the accusation against them. However, the World War II price act involved in the $Y a k u s$ case was not self-executing, but set itp a vague standard, "fair and equitable prices," and empowered an adininistrator to promulgate regulations which "in his judgment will be generally fair and equitable and will effectuatc the purposes of this act." This statute was upheld against void for vagueness attack.

53 See People v. Associated Oil Co., 211 Cal. 93, 294 Pac. 717 (1930). The statute, Cal. Stats. 1929, p. 923, set up the standard of "unreasonable waste." The administrator was to determine what would be unreasonable. This was upheld against vagueness attack. Sec also Hewitt v. Board of Medical Examiners, supra note 35. The board was given power to revoke hicenses for "unprofessional conduct." The statute specified that "all advertising of medical business in which grossly improbable statements are made" was unprofessional conduct. The board was given power to determine what was "improbable." This statute, Cal. Stats. 1901, p. 46 , was held void for vagueness and also an unlawful delegation of power.

54 Supra note 43.

55189 Cal. at 689, 209 Pac. at 898.

56 Supra note 3. 
"field" was not defined by the statute. This was attacked on both vagueness grounds and as an unlawful delegation of legislative power. The Supreme Court said these two questions were "interrelated." The District Court of Appeals had invalidated the statute on both grounds.

This close correlation between the two separate rules may lead to confusion. Delegation of legislative power involves a question of whether the statute as written provides the administrator with some yardstick to follow in making his rules and regulations. ${ }^{57}$ The vagueness question as respects this type of administrative statute should be directed toward the regulation as promulgated and not the statute. The statute provides little warning, and its general policy forms the standard of guilt only when read with the regulations which are issued. It would seem that the only time a statute could be held void for vagueness and an unlawful delegation of legislative power at the same time would be when the statute had portions which are self-executing, such as a parking ordinance, and portions which are entirely dependent upon the administrator promulgating rules before anyone is subject to the law. This distinction has not been drawn by the cases.

The California courts ${ }^{58}$ have indicated that to avoid an unlawful delegation of legislative power the statute must declare the policy of the law and fix the yardstick for the guidance of the administrator. They have not been uniform in their requirement of how definite this yardstick must be. Until this is clarified the unlawful delegation rule may be used to void statutes, which, because of the delegation to define terms, would have otherwise escaped attack as.being void for vagueness: This difficulty is avoided to a large extent in the Federal system by the allowance of very broad delegation. ${ }^{59}$ The only real void for vagueness question involved in statutes which delegate power is encountered where there is delegation of judicial power. Here the statute must supply a standard of adjudication in the same manner as in self-executing statutes where the judiciary will be adjudicating.

The latest pronouncement of the California Supreme Court on delegation is in the Wooton decision. On the facts, wide power is delegated which might indicate closer proximity to the Federal view. However, the court upheld the delegation in a special way. The administrators were found to have used a fixed standard for years. The legislature in reenactments of the

57 See Wooton v. Bush, supra note 3. American Distilling Co. v. State Board of Equalization, 55 Cal. App. 2d 799, 805, 131 P.2d 609, 612 (1942) "It is true that the legislature may delegate authority to administrative boards to adopt and enforce reasonable rules for carrying into effect the expressed purposes of a statute even though such rules include the authorization to exercise discretion ... provided that discretion is not purely arbitrary and does not amount to a sanction to add to or change the statute or confer upon the board a right to determine what the law shall be in a particular case." See State Board of Dry Cleaners v. Thrist-D-Lux, 40 A.C. 439, 254 P.2d 29 (1953) ; Board of Harbor Commissioners v. Excelsior Redwood Co., 88 Cal. 491, 26 Pac. 375 (1891); Jersey Maid Milk Products Co. v. Brock, 13 Cal.2d 620, 91 P.2d 577 (1939); Miller' v. Mumicipal Court, 22 Cal.2d 818, 142 P.2d 297 (1943).

is Cases cited note 57 supra.

59 A.L.A. Schechter Poultry Corp. v. U.S., 295 U.S. 495 (1935) seems to be the only limit. Since 1932, the only challenge to delegation of legislative power on economic regulation was in a dissent in Boyce Motor Lines v. U.S., 342 U.S. 337 (1952). 
statute had not changed this standard, therefore it became a legislative standard by implication.

\section{VOID FOR VAGUENESS AND FREE SPEECH, PRESS, AND ASSEMBLY}

A comparatively large number of the void for vagueness holdings have involved statutes which regulate activities bordering upon the fundamental rights of free speech, press and assembly. It has clearly been the rule that statutes in such proximity to constitutionally protected rights require a higher degree of certainty than others. ${ }^{60}$ The emphasis in these cases has been on the standard of guilt established by the statute in question. ${ }^{\text {(1 }}$ The essence of these holdings is that with a flexible standard of guilt because of the vagueness, the chances are great that enforcement can arbitrarily prohibit free speech and the other fundamental rights. The field of constitutional law centering on the question of free speech, press, and assembly, the "clear and present danger rule" ferred position" are in ferment at the present time. States may in the future be deemed to have more power ${ }^{63}$ to regulate certain activities heretofore held to be beyond interference. ${ }^{64}$ But, no matter where the United States Supreme Court finally comes out on what is and what is not a violation of free speech, press and assembly, there will still have to be a clear line drawn in the statutes regulating this conduct so that there is less chance of enforcing it over into the protected area. Granting to the states more power to regulate in these areas only shifts the dividing line to a new point of reference. These statutes are going to have to be clear.

\section{PREDICTABILITY}

There has been great vitality to the void for vagueness rule in the fields of free speech, press and assembly. Perez $v$. Shar $p^{65}$ might be used as the starting point to push beyond these cases. Sections 60 and 69 of the Civil

60 Winters v. New York, 333 U.S. 507 (1948).

61 A penal statute which "does not aim specifically at evils within the allowable area of state control but, on the contrary, sweeps within its ambit other activities that in ordinary circumstances constitute an exercise of freedom of speech or of the press . . . lends itself to harsh and discriminatory enforcement by local prosecuting officials, against particular groups deemed to merit their displeasure ...." Thornhill v. Alabama, 310 U.S. 88 at 97 (1939). This was quoted in In re Harder, 9 Cal. App. 2d 153, 49 P.2d 304 (1935) and In re Bell, 19 Cal. 2d 488, 122 P.2d 22 (1942). See also Stromberg v. Calif., 283 U.S. 359 (1931), Herndon v. Lowrey, 301 U.S. 242 (1937), In re Blaney, 30 Cal. 2d 643, 184 P.2d 892 (1947) and Edwards v. Calif., 314 U.S. 160 (1941).

69 Dennis v. United States, 341 U.S. 494 (1951).

63 Seven-Up Bottling Co. v. Grocery Drivers' Union, 40 A.C. 373, 254 P.2d 544 (1953), Sommer v. Metal Trades, 40 A.C. 396, 254 P.2d 559 (1953). For U.S. Supreme Court cases on this point, see Giboney v. Empire Storage Co., 336 U.S. 490 (1949), Hughes v. Superior Court, 339 U.S. 460 (1950); International Brotherhood of Teamsters v. Hanke, 339 U.S. 470 (1950); Building Service Employees v. Gazzam, 339 U.S. 532 (1950).

64 Lockheed Aircraft Corp. v. Superior Court, 28 Cal.2d 481, 171 P.2d 21 (1946), relearing denied, In re Porterfield, 63 Cal. App. 2d 518, 147 P.2d 15 (1944), rev'd, 28 Cal.2d 91, 168 P.2d 706 (1946); Los Angeles v. Los Angeles Building and Construction Trades Council, 94 Cal. App. 2d 36, 210 P.2d 305 (1949), aff'd, 109 Cal, App. 2d 81, 240 P.2d 16 (1952).

6532 Cal. 2 d 711, 198 P.2d 17 (1948). 
Code were held void for vagueness in the Perez case. They provide that "no license may be issued authorizing the marriage of a white person with a negro, mulatto, mongolian or member of the Malay race .... All marriages of white persons with negros, mongolians, members of the Malay race or mulattoes are illegal and void." The statutes were held invalid as unconstitutional interference with freedom of religion, i.e., free exercise of religion and to participate in the sacraments of the Catholic religion. The alternative holding was that these statutes were void for vagueness in that they did not establish any criterion as to what constitutes a mulatto, a black, or a white. It can be argued that any of the more fundamental rights deserve a more clearly drafted statute than is ordinarily required.

The Orloff case ${ }^{66}$ illustrates that if the original encounter is in some non-penal matter there is less chance that the statute will be held void for vagueness, and it is more likely that judicial construction will supply a standard. Therefore, the judicial history of a statute is very important.

The Associated Oil case ${ }^{67}$ illustrates another factor which must be kept in mind. If the statute provides for injunction, and it is not the enjoining of a fundamental right like free speech, press or assembly, the penalty will often be regarded as not harsh enough to require strict clarity. Warning may be furnished by the injunction rather than the statute.

With the increased amount of legislation covering new fields, by necessity there will be a need for broad statutes. An important consideration which the courts have noted is what alternatives are available to the wording that is used. ${ }^{68}$ Showing more practical alternatives may be a way to build a strong argument for voiding a statute which could have been more clearly drafted without impairing its broad coverage. Also, administrative construction will be given great weight.

The gloss of age has been deemed important, mainly because long-used judicial interpretation will clarify meaning. ${ }^{69}$ However, two cases in California, ${ }^{70}$ have held very old statutes void for vagueness.

It should be noted that although a phrase has the appearance of being very vague, to a particular trade or profession it may have a definite meaning and therefore will not be subject to attack. ${ }^{i 1}$

The relative weakness of the void for vagueness rule should be borne in mind. So far the rule has been used successfully only in a few cases where there were not alternative grounds. The early cases developing the rule were ones where the doctrine of strict construction for penal statutes was used. As has been observed, this is impractical in modern times. Many of the leading cases $^{72}$ also involve the unlawful delegation question,

o6 Supra note 4.

07 Supra note 53 .

os People v. Yates, supra note 21.

${ }^{69}$ See concurring opinion by Rutledge, J., in Screws Case, supra note 14 at 119.

70 Ex Parte Lockett, supra note 7; Sharp v. Lippold, supra note 65.

71 People v. Bradford, supra note 6; Cresci v. Brock, 225 P.2d 685 (1950).

72 In re Peppers, supra note 43; Wooton v. Bush, supra note 3; Hewitt v. Board of Medical Examiners, supra note 35. 
which may weaken the vagueness holding. All the free speech labor cases are closely tied to the particular outlook of the day as to what free speech means, and are treated as special so that their citation for propositions in non-free speech vagueness cases would be incorrect.

The basic idea has developed from the consideration that penalties may be harsh and therefore, to be fair, the statutes should be as clear as possible in order to give umform application to all and to give adequate warnmg. This has had to do with criminal law and penal statutes. Yet, it is obvious that certain statutes which would not be regarded as penal have a much more burdensome effect upon the defendant than might some criminal sanctions. This has been recognized in the license revocation situation and in the free speech cases. ${ }^{73} \mathrm{~A}$ citation used in the Ward case $^{74}$ indicated that void for vagueness is a rule that has application in civil as well as criminal legislation. A strong argument can be made for carrying the rule into new fields not penal, where legislative drafting is "penalizing" those who seek justice.

It would seem that the void for vagueness rule has taken only its initial step in California. There are no hard and fast rules which can be relied on in the close cases. The decisions would seem to be a result of measuring the inany factors and considerations pointed out above. About the only safe generalization is that it takes a very vague statute to invoke the rule. David Bruce Harriman

ז3 "While the instant statute does not directly impose criminal penalties, it does provide for injunctive relief in event of violation .... and this is a coersive measure." In re Blaney, supra note 61 at 653,184 P.2d at 899.

74 Ward v. Auctioneers, supra note 12 at 186,153 P.2d at 766, in referring to the Cline case, supra note 11, the California court said: "The court held that the principle of due process of law requiring reasonable certainty ... has application in civil as well as criminal legislation." 